УДК 343.98:343.326

DOI https://doi.org/10.32844/2618-1258.2019.3-2.37

ЧОРНИЙ Г.О.

\title{
МЕТОДИКА РОЗСЛІДУВАННЯ ТЕРОРИСТИЧНИХ АКТІВ: ПРОБЛЕМИ ФОРМУВАННЯ НА СУЧАСНОМУ ЕТАПІ
}

Стаття присвячена розгляду проблеми формування методики розслідування терористичних актів на сучасному етапі розвитку криміналістики. Автор статті розглядає криміналістичну методику як систему інтегрованих наукових положень i сформованих на їх основі комплексів методичних рекомендацій та слідчих технологій у вигляді типових інформаційних моделей, спрямованих на оптимальне здійснення розслідування та попередження (запобігання) злочинів. Методика розслідування терористичних актів розглядається як вид криміналістичної методики. До складу цього виду входять: 1) криміналістична характеристика терористичного акту; 2) обставини, що підлягають з'ясуванню; 3) типові слідчі ситуації, особливості висунення та перевірки версій на початковому етапі розслідування злочинів терористичної спрямованості; 4) проміжні завдання та комплекс слідчих гласних та негласних дій на початковому етапі; 5) проміжні завдання та комплекс слідчих (розшукових) гласних та негласних дій на наступному етапі розслідування злочинів терористичної спрямованості; 6) заходи усунення протидії розслідуванню злочинів терористичної спрямованості; 7) профілактична діяльність під час розслідування злочинів терористичної спрямованості.

Особливу увагу автор приділяє типовим слідчим ситуаціям, серед яких розглядає такі: 1) особа, підозрювана у вчиненні терористичного акту з використанням вибухового пристрою, загинула, така особа відома; 2) особа, підозрювана у вчиненні терористичного акту з використанням вибухового пристрою, загинула, така особа невідома; 3) особа, підозрювана у вчиненні терористичного акту з використанням вибухового пристрою, не затримана поліцією, але наявна інформація, яка дозволяє організувати іiї пошук. Запропоновані слідчі ситуації передбачають висунення і перевірку таких типових версій під час розслідування терористичного акту: 1) було вчинено терористичний акт із застосуванням зброї, вибуху, підпалу або іншим способом; 2) відбулося вчинення злочину із застосуванням зброї, вибуху, підпалу без мети порушення громадської безпеки, впливу на органи держави, залякування населення тощо; 3) відбулося злочинне порушення встановлених вимог та правил; 4) причиною вибуху, пожежі, руйнування стала непереборна сила (стихійне лихо). У роботі розглядаються особливості проведення таких слідчих дій, як огляд, допит свідків, потерпілих, підозрюваних, а також особливості призначення та проведення експертиз.

Ключові слова: терористичний акт, розслідування злочину, криміналістична характеристика, слідчі діi.

The article is sanctified to consideration of problem of forming of methodology of investigation of assassinations on the modern stage secret service of criminalistics. The author of the article examines criminalistics methodology as system of the integrated scientific positions and complexes of methodical recommendations and inquisitional technologies formed on their basis as typical informative models, crimes sent to optimal realization of investigation and warning (prevention). Methodology of investigation of assassinations is examined as specific criminalistics methodologies in the complement of that enter: 1. Criminalistics description of assassination; 2. Circumstances that is subject to finding out; 3. Typical inquisitional situations, features of advancement

ЧОРНИЙ Г.О. - кандидат юридичних наук, доцент, доцент кафедри криміналістики (Національний юридичний університет імені Ярослава Мудрого) 
and verification of versions on the initial stage of investigation of crimes of terrorist orientation; 4. Intermediate tasks and complex of the inquisitional vowel and secret operating are on the initial stage; 5. Intermediate tasks and complex of inquisitional (of criminal investigation) vowel and secret actions are on the next stage of investigation of crimes of terrorist orientation; 6 . Measures of removal of counteraction to investigation of crimes of terrorist orientation; 7. Prophylactic activity is at investigation of crimes of terrorist orientation. The special attention an author spares to the typical inquisitional situations among that examines: 1 . The person suspected of assassinating with the use of explosive device perished, personality of her is known. 2. The person suspected of assassinating with the use of explosive device perished, personality of her is unknown. 3. Person suspected of assassinating with the use of explosive device, present information that allows to organize his search not detained, but.

The offered inquisitional situations envisage advancement and verification of such typical versions at investigation of assassination, as: 1 . An assassination was perfect with application of weapon, explosion, arson, or by other method. 2. The commission of crime takes place with application of weapon, explosion, arson without the aim of public security, influence breach on the organs of the state, intimidation of population and others like that. 3. Criminal violation of the set requirements and rules takes place. 4. Reason of explosion, fires, destructions is an act (natural calamity) of providence. The features of realization of such inquisitional actions as review are also examined in-process; interrogation of witnesses, suffering, suspected; features of setting and realization of examinations.

Key words: assassination, investigation of crime, criminalistics description, investigators actions.

Вступ. Підвищений рівень терористичної небезпеки вимагає на сучасному етапі розвитку науки криміналістики інноваційних підходів до розробки та формування новітніх методик розслідування терористичних актів.

Постановка завдання. Метою статті є аналіз сучасних наукових підходів до формування методик розслідування злочинів та спроба вирішення конкретної проблеми формування структури методики розслідування терористичних актів.

Результати дослідження. Зростання терористичної загрози ставить перед криміналістикою нові виклики щодо розробки та формування відповідної методики розслідування терористичних актів.

Під час формування методики розслідування терористичних актів необхідно діяти в таких наукових площинах: визначити місце методики розслідування терористичних актів у структурі класифікації криміналістичних методик; визначити структуру та зміст методики розслідування терористичних актів.

Визначаючи місце методики розслідування терористичних актів у структурі класифікації криміналістичних методик, необхідно зазначити наступні положення. По-перше, криміналістична методика розглядається як система інтегрованих наукових положень і сформованих на їх основі комплексів методичних рекомендацій та слідчих технологій у вигляді типових інформаційних моделей, спрямованих на оптимальне здійснення розслідування та попередження (запобігання) злочинів [14, с. 100]. Р.С. Бєлкін вказує, що система є комплексом порад типізованого характеру, тобто вона відбиває типові особливості розслідування злочинів певного виду [1, с. 302-303]. Сьогодні в криміналістиці існує декілька наукових підходів і теорій щодо класифікації або диференціації таких методик [2, с. 204; 4, с. 571-576; 6, с. 490; 13, с. 90; 14, 189-190; 17, с. 98]. Більш вдалою, на нашу думку, $є$ наукова позиція професора В.А. Журавля, який, керуючись конфігурацією системи криміналістичних методик розслідування злочинів, запропонував їх упорядкування за горизонталлю та вертикаллю [6, с. 189-190]. Відповідно до наведеної класифікації методика розслідування терористичних актів розглядається як вид криміналістичної методики. Критично проаналізувавши наукові положення криміналістів [8. с. 16; 4, с. 571-576], ми вважаємо, що до структури методики розслідування терористичного акту доцільно віднести такі складники: 1) криміналістичну характеристику терористичного акту; 2) обставини, що підлягають з'ясуванню; 3) типові слідчі ситуації, особливості висунення та перевірки версій на початковому етапі розслідування злочинів терористичної спрямованості; 4) проміжні завдання та комплекс слідчих 
(розшукових) гласних та негласних дій на початковому етапі; 5) проміжні завдання та комплекс слідчих (розшукових) гласних та негласних дій на наступному етапі розслідування злочинів терористичної спрямованості; 6) заходи усунення протидії розслідуванню злочинів терористичної спрямованості; 7) профілактичну діяльність під час розслідування злочинів терористичної спрямованості $[4$, с. $490 ; 9$, с. $334-335 ; 11$, с. $128-130 ; 13$, с. $155 ; 14$, с. $100 ; 15$, с. $485-486]$.

Для формування методики розслідування терористичних актів важливе значення мають такі елементи криміналістичної характеристики: спосіб вчинення злочину; типові сліди; місце, час та обстановка; особа злочинця; особа потерпілого.

Cпосіб вчинення злочину передбачає наявність дій, спрямованих на підготовку до вчинення терористичного акту, безпосереднє вчинення злочину та дії, спрямовані на приховування вчиненого злочину. До підготовчих дій необхідно віднести дії, спрямовані на підшукання та вербування осіб, які надали згоду на вчинення терористичного акту; придбання, виготовлення необхідних документів, зброї, вибухових речовин та/або вибухових предметів; детальну розробку плану вчинення злочину з урахуванням його місця, часу та інших суттєвих ознак; планування дій, спрямованих на приховання злочину (підготовку алібі, житла та/або приміщень 3 метою подальшого переховування після вчинення терористичного акту, резервування та придбання квитків для виїзду в інше місто або країну). Способи вчинення терористичного акту можуть бути виражені у двох формах: 1) вчинення терористичного акту; 2) погроза вчинення такого акту. Першу форму залежно від наявності та характеру причинно-наслідкових зв'язків між діями та настанням суспільно небезпечних наслідків поділяють на: 1) способи, зміст яких складає вплив, який становить небезпеку загибелі людей, створює небезпеку для їх життя чи здоров'я або заподіює значну майнову шкоду чи настання інших тяжких наслідків. До таких дій слід віднести застосування зброї, вчинення вибухів, підпалів. Із застосуванням зазначених способів вчиняються вбивства керівників держав і урядів, лідерів провідних партій або громадських організацій, дипломатичних представників тощо; 2) способи впливу, які створюють умови для виникнення небезпеки загибелі людей. До таких дій необхідно віднести організацію обвалів та аварій на об’єктах життєзабезпечення населення, блокування транспортних систем, затоплення, зараження джерел води або продуктів харчування, розповсюдження мікробів, які можуть спричинити епідемії, епізоотії, втручання в електронні системи державних та приватних організацій, установ, напади на об’єкти підвищеної небезпеки (атомні станції, підприємства хімічної промисловості тощо).

Особливістю способів приховування терористичного акту є те, що злочинці, як правило, не намагаються приховати саму подію та її наслідки, навпаки, вони вчиняють такі дії, щоб вона стала відома якнайбільшому колу осіб (публічно беруть відповідальність за вчинений злочин, здійснюють його відеофіксацію з наступним розміщенням у засобах масової інформації та в мережі «Інтернет». Дії, спрямовані на приховування терористичного акту, злочинці застосовують на підготовчому етапі шляхом: 1) вибору місця, часу, знарядь вчинення злочину, які унеможливлюють розкриття злочину; 2) маскування підготовчих до злочину дій під виробничу або іншу діяльність; 3) маскування вогнепальної зброї, вибухових речовин та пристроїв тощо. Після вчинення терористичного акту злочинці здійснюють такі дії: 1) приховування або знищення знарядь вчинення злочину, авто- та мототранспорту, використаного одягу; 2) зміну місця проживання; 3) непомітний відхід з місця вчинення злочину тощо.

Типові сліди злочину перебувають у залежності із способом вчинення злочину. У разі використання вогнепальної зброї можуть бути виявлені гільзи, кулі, сліди їх застосування, зброя, яку злочинці залишили на місці події. У разі підпалів виявляються такі сліди: засоби підпалу або їх фрагменти, сліди рідин, речовин, засоби їх транспортування та переміщення, ознаки проникнення на місце вчинення злочину, ознаки створення умов для виникнення труднощів при виявленні підпалу та його гасіння. Використання вибухових пристроїв та речовин супроводжується виявленням таких слідів: воронки (як місця найбільш інтенсивних руйнувань), деформації предметів, частин і деталей механізмів, електроприводів, електродетонаторів, капсуль-детонаторів, акумуляторів, а також слідів впливу вибуху на одязі та тілах потерпілих.

Micце, час, обстановка вчинення злочину мають суттєве значення в структурі криміналістичної характеристики. Обстановка вчинення терористичного акту зумовлена ситуацією безпеки для самих злочинців при вчиненні злочину. Це відсутність або слабка охорона, відключення засобів візуального спостереження за об'єктом нападу, погодні умови. Вибір об'єкта залежить від його важливості з погляду державного значення, громадського резонансу після вчинення злочину. Такими, як правило, є станції метро, супермаркети, аеропорти, вокзали, готелі, стадіони, 
споруди військового призначення, а також інші місця великого скупчення людей. Час вчинення зумовлений, з одного боку, найбільшою безпекою для реалізації злочинних намірів, а з іншого знищенням якомога більшої кількості людей, завданням тілесних ушкоджень, руйнувань 3 метою тиску на владу, дестабілізації обстановки у районі, місті, державі.

Особа злочинця характеризується різноманітними соціальними, віковими, освітніми даними. Поняття «особа злочинця» під час вчинення терористичних актів має декілька таких аспектів: організація, група, виконавець. Терористична організація або група має чітку ієрархічну будову. У таких групах існує певна підпорядкованість ії членів, відповідний порядок життя, проводиться ідеологічна обробка майбутніх виконавців терористичних актів. Відповідно до мети та завдання терористичного акту обирається виконавець з урахуванням його професійних здібностей, соціальної, релігійної та політичної спрямованості.

Особа потерпілого характеризується наявністю певних відносин з органами державної влади чи органами місцевого самоврядування, об'єднаннями громадян, юридичними особами в ситуації, коли терористичний акт вчиняється внаслідок саме виконання ними певних владних повноважень. Проте потерпілими від зазначеного злочину найчастіше $є$ особи, які випадково опинилися на місці події. Важливе значення мають наслідки вчинення самого терористичного акту, який викликає у невизначеного кола громадян емоційні переживання у формі страху, жаху, паніки. Такі страждання тягнуть за собою соціальну агресію, суспільну паніку, масовий психоз, що призводить до невдоволення громадян щодо представників влади або органів місцевого самоврядування, правоохоронців. У громадян виникають та довго підтримуються різні фобії та манії (страх перебування у багатолюдних місцях, замкненому середовищі, страх здійснення авіаперельотів або пересування на залізничному транспорті тощо).

Обставини, які підлягають з'ясуванню. Під час проведення досудового слідства при розслідуванні терористичних актів типовими обставинами, які підлягають з'ясуванню у кримінальному провадженні, є такі: 1) хто, коли та за яких обставин повідомив про вчинення терористичного акту чи загрозу його вчинення, що саме було повідомлено; 2) яка саме подія відбулася - терористичний акт, убивство на замовлення з використанням вогнепальної зброї та/або вибухового пристрою чи речовини, кримінальне правопорушення внаслідок недотримання відповідних правил та вимог безпеки на виробництві, нещасний випадок, кримінальні розбірки, нещасний випадок, інше; 3) коло потерпілих осіб внаслідок вчинення терористичного акту; 4) хто $є$ об'єктом впливу терористичного акту - представники органів влади, місцевого самоврядування, громадських організацій, юридичних осіб або пересічні громадяни; 5) спосіб вчинення терористичного акту; 6) знаряддя вчинення терористичного акту (за допомогою вибухового пристрою (саморобного або промислового), із застосуванням вогнепальної зброї, транспортного засобу, паливно-мастильних матеріалів тощо); 7) що являє собою місце вчинення терористичного акту, який час його вчинення та обстановка; 8) чи намагалися злочинці до вчинення терористичного акту будь-яким чином контактувати з представниками влади, громадських організацій, юридичних осіб або з громадянами, їх родичами; 9) чи намагалися злочинці приховати підготовчі дії до вчинення терористичного акту з використанням відповідних знарядь його вчинення; 10) яка основна мета, завдання та мотиви вчинення злочинних дій.

Tипові слідчі ситуації та версії. Слідчі ситуації, які виникають під час розслідування терористичних актів, зумовлені тим, що ст. 258 КК України передбачає дві форми терористичного акту - вчинення терористичного акту та погрози його вчинення. Таким чином, всі слідчі ситуації можливо поділити на дві основні групи - вчинення терористичного акту, висловлення погроз щзодо вчинення терористичного акту. До першої групи слідчих ситуацій необхідно віднести випадки застосування зброї, вибухів, підпалів, які створювали небезпеку для життя чи здоров'я людини або заподіяння значної майнової шкоди чи настання інших тяжких наслідків, якщо такі дії були вчинені з метою порушення громадської безпеки, залякування населення, провокації воєнного конфлікту. До другої групи відносять випадки висловлення погроз вчинення вищезазначених дій з тією ж метою. Залежно від характеру початкової інформації першої групи розглядаються такі слідчі ситуації: 1) була отримана інформація про існування терористичного формування (організації, групи); 2) була отримана інформачія про вчинення терористичного акту або про погрозу його вчинення. За джерелом інформації класифікація слідчих ситуацій зазначеної групи така: 1) була отримана інформація від злочиния про вчинення терористичного акту або погроза його вчинення; 2) потерпілі звернулись з інформачією про вчинення терористичного акту; 3) відки заявили про вчинення терористичного акту; 4) про вчинення терористичного акту стало відомо із засобів масової інформаиії. 
За наявності інформації про злочинця під час його затримання на початковому етапі виділяють такі типові слідчі ситуації: 1) особа, підозрювана у вчиненні терористичного акту з використанням вибухового пристрою, загинула, така особа відома; 2) особа, підозрювана у вчиненні терористичного акту з використанням вибухового пристрою, загинула, така особа невідома; 3) особа, підозрювана у вчиненні терористичного акту з використанням вибухового пристрою, не затримана поліиією, але наявна інформація, яка дозволяє організувати їі пошук. Запропоновані слідчі ситуації передбачають висунення і перевірку таких типових версій під час розслідування терористичного акту: 1) було вчинено терористичний акт із застосуванням зброї, вибуху, підпалу або іншим способом; 2) відбулося вчинення кримінального правопорушення із застосуванням зброї, вибуху, підпалу без мети порушення громадської безпеки, впливу на органи держави, залякування населення тощо; 3) відбулося злочинне порушення встановлених вимог та правил (порушення вимог законодавства про охорону праці (ст. 271 КК України), порушення правил безпеки під час виконання робіт з підвищеною небезпекою (ст. 272 КК України); 4) причиною вибуху, пожежі, руйнування стала непереборна сила (стихійне лихо).

Особливості розслідування терористичного акту. Процес розслідування терористичних актів ситуаційно зумовлений і впливає на обрання відповідних слідчих (розшукових) гласних та негласних дій.

Огляд місия подіï має завдання пошуку, виявлення та вилучення слідів вчинення терористичного акту, недопущення їх пошкодження та/або знищення, недопущення жертв серед населення та учасників огляду від нерозірваних (неспрацьованих) вибухових пристроїв. На початковому етапі огляду можливе виникнення неконфліктних ситуацій, коли вчинення злочину має дійсне відображення, а також у разі неповного відображення або коли злочин не відображається явно (конфліктна ситуація). У разі вчинення терористичного акту шляхом застосування вибухових пристроїв на місці події виявляються їх фрагменти, металеві, пластмасові, скляні шматки, клаптики паперу, фрагменти годинникових механізмів, батарей, тумблерів, шматки дротів, продуктів вибухових речовин, які не прореагували, тверді продукти вибуху, вражаючі елементи - гайки, болти, металева стружка тощо. Особлива увага приділяється виявленню мікрослідів вибуху, які у сукупності з об'єктами - носіями - диференціюються за слідоутворюючим об'єктом вибухового пристрою або речовини та виду контактного зв'язку на сліди накладення, включення, нашарування. Зазначені сліди виявляються на предметах, які знаходяться на місті події, одязі потерпілих, свідків. У разі застосування вогнепальної зброї фіксуються та вилучаються кулі, гільзи та інші сліди.

Допит потерпілих має свої особливості, які продиктовані тим, що злочином їм завдано моральної, фізичної або майнової шкоди. Здебільшого фіксується психотравма особистості, прояви ремінісценції, посттравматичний стресовий розлад пам'яті, що суттєво впливає на якість показань потерпілих. Допит потерпілих передбачає з'ясування таких обставин: де, коли та за яких обставин вчинено злочин; коли та у зв'язку з чим потерпілий був на місці вчинення терористичного акту; хто ще був на місці події та разом з ним; який був характер дій потерпілого та оточуючих до, під час та після вчинення злочину; яке було його просторове розташування; яка була кількість злочинців та яким чином вони рухались на місці події; як звертались один до одного; яка шкода та за яких обставин була заподіяна потерпілому; у якому стані потерпілий знаходився на місті події. Під час допиту свідків 3'ясовуються такі питання: коли, де, у зв'язку з чим особа перебувала на місці події; який був ії маршрут руху; де вона була під час вибуху; стан її органів сприйняття; які були обставини вибуху, пожежі, застосування зброї; яка була обстановка на місці вибуху, пожежі; які наслідки злочину особа безпосередньо сприймала; хто ще знаходився на місці події; яка кількість, характер та послідовність дій кожного із злочинців тощо.

Допит підозрюваного має особливості, які зумовлені процесуальним станом особи, діями, які вона виконувала в терористичній організації (організатор, керівник, виконавець, пособник, підбурювач), способом вчинення злочину. До основних питань, які підлягають з'ясуванню, відносять такі: коли, де, у кого та за яких обставин виник умисел на вчинення терористичного акту саме у такий спосіб; хто, де, коли та під чиїм керівництвом здійснював планування злочину; які були обов'язки кожного з учасників групи; коли, де, ким та за яких обставин були придбані (виготовлені) вибухові пристрої, речовини, зброя; де та як довго зберігався вибуховий пристрій; де, коли та за яких обставин були набуті спеціальні навички поводження з вибуховими пристроями, речовинами (використання спеціальної літератури, служба в збройних силах, служба в гарячих точках, робота підривником у шахті тощо); коли, яким шляхом та разом з ким особа прибула на місце вчинення злочину тощо. 
Призначення та проведення судових експертиз здійснюється за такими напрямами: судово-медична експертиза; експертиза зброї та слідів і обставин ії використання, яка вирішує завдання встановлення належності об’єктів до вогнепальної зброї або конструктивно подібних до неї стріляючих виробів, встановлення належності об'єктів до боєприпасів вогнепальної стрілецької зброї або конструктивно подібних до них виробів, визначення виду, системи (моделі) та калібру вогнепальної зброї та боєприпасів до неї, а також конструктивно подібних до них виробів; транспортно-трасологічна експертиза; пожежно-технічна експертиза; портретна експертиза; експертиза вибухових пристроїв, яка вирішує завдання визначення факту вибуху вибухового пристрою на місці події, визначення виду вибуху, належності об'єкта до вибухових пристроїв (боєприпасів) та визначення класифікаційної категорії пристрою, а також визначення потужності вибуху вибухового пристрою; експертиза вибухових речовин і продуктів вибуху (пострілу).

Висновки. Таким чином, запропонована структура методики розслідування терористичних актів дозволяє ефективно здійснювати організацію та планування розслідування та швидко розкривати злочини, які класифікуються як терористичні акти.

\section{Список використаних джерел:}

1. Белкин Р.С. Курс криминалистики : в 3 т. Т.3. Криминалистические средства, приемы, рекомендации. Москва : Юристъ. 1997. С. 302-303.

2. Веліканов В.С. Родові, видові, підвидові, комплексні та модифікуючі методики розслідування злочинів. Питання боротьби зі злочинністю : збірник наукових праць /редкол. В.І. Борісов та ін. Харків : Право. 2009. Вип. 18. С. 204.

3. Возгрин И.А. Структура частных криминалистических методик расследования преступлений. Криминалистика : учебник / под ред. И.Ф Крылова, А.И. Быстрыкина. Москва : 2001. C. 571-576.

4. Ищенко Е.П., Топорков А.А. Криминалистика : учебник / под. ред. Е.П. Ищенко. Москва : ИНФРА-М, 2006. С. 490.

5. Колисниченко А.Н. Общие положения методики расследования отдельных видов преступлений. Советская криминалистика. Методика расследования отдельных видов преступлений / под ред. В.Е Лисиченко. Киев : Высшая школа, 1988. С. 16.

6. Журавель В.А. Криміналістичні методики: сучасні наукові концепції : монографія. Харків : Вид. агенція «Апостіль». 2012. С. 98.

7. Кабанов П.А. Политический терроризм. Криминологическая характеристика и меры сдерживания. Нижнекамск, 1998. С. 48.

8. Челышева О.В. К вопросу о систематизации частных криминалистических методик расследования. Ученье записки юридического факультета Санкт-Петербургского гуманитарного университета профсоюзов. Вып. 5. Актуальные проблемы юриспруденции в условиях становления правовой системы и гражданского общества в России. Санкт-Петербург, 2000. С. 91.

9. Чурилов С.Н. Криминалистическая методика: история и современность. Москва, 2002. C. $189-190$.

10. Шурухнов Н.Г. Криминалистика : учебник. 2-е изд., исправ. и доп. Москва : Эскмо, 2008.

11. Косарев С.Ю. История и теория криминалистических методик расследования преступлений / под. ред. В.И. Рохлина. Санкт-Петербург Юрид. центр, 2006. С. 334-335.

12. Шмонин А.В. Методика расследования преступлений : учеб. пособие. Москва : ЗАО Юстицинформ, 2006. С. 128-130.

13. Шмонин А.В. Методология криминалистической методики : монография. Москва : Юрлитинформ, 2010. С. 98.

14. .Шмонин А.В. Методика расследования преступлений : учебное пособие. Москва : ЗАО Юстицинформ, 2006. С. 155.

15. Щур Б.В. Теоретичні основи формування та застосування криміналістичних методик : монографія. Харкыв : Харків юридичний, 2010. С. 100.

16. Яблоков Н.П. Общие положения криминалистической методики расследования преступлений. Криминалистика : учебное пособие / отв. ред. Н.П. Яблоков. Москва : Изд-во.БЕК, 1995. C. 485-486. 